\title{
Origen and evolution of gypsum stromatolites in salars of the Andes highlands, northern Chile
}

\author{
Oscar Ercilla Herrero \\ 1 Servicio Nacional de Geología y Minería (SERNAGEOMIN), Avda. Santa María 0104, Providencia, Santiago. \\ oscar.ercilla@sernageomin.cl
}

\begin{abstract}
In several salars in the Andes Highlands in Chile, gypsum stromatolites have been described. Stromatolites are structures with organic origin and they are normally formed by carbonates. Field observations achieved in five salars in the Andes of northern Chile have permitted to recognize six stages during the gypsum stromatolites formation, from the growth of the organic mats to their almost disappearance by local erosive agents. The six stages are: 1) formation of the organic mat and start of the mineral structure development, 2) growth of the domes structure by trapping of gases in side of the organic mat, 3) development of the crystal gypsum wall , 4) death of the organic colony and exposition of the stromatolitic domes to the subaerial environment, 5) initial destruction of the dome structure and start of the central cavity filling and 6) final degradation of the structures and formation of the mounds with the gypsum crystals at the top.
\end{abstract}

Keywords: Stromatolite, Salars, Gypsum, Andes Highlands, Chile.

RESUMEN. Origen y evolución de estromatolitos de yeso en salares del altiplano andino, norte de Chile. En varios salares situados en el altiplano andino en Chile se han podido observar formaciones estromatolíticas de yeso. Los estramatolitos son estructuras de origen orgánico que habitualmente están constituidas por carbonatos. Observaciones realizadas en cinco salares ubicados en los Andes del norte de Chile han permitido identificar seis etapas durante la formación de dichos estromatolitos, desde la creación de los tapices orgánicos hasta su destrucción por los agentes erosivos locales. Las seis etapas son las siguientes: 1) formación del tapiz orgánico microbiano e inicio del establecimiento de la estructura mineral, 2) generación de las cúpulas del estromatolito por confinamiento de gases en el interior del tapiz orgánico, 3) desarrollo de la pared mineral constituida por grandes cristales de yeso, 4) muerte de la colonia microbiana y exposición de las cúpulas estromatolíticas al ambiente subáereo, 5) destrucción parcial de la estructura y comienzo de su relleno y 6) destrucción total de la estructura y formación de montículos con los cristales de yeso en la parte superior. 


\section{Introduction}

The stromatolites or microbialites are organic structures originated by the activity of a benthic microbial community that traps and binds detrital sediment and/or generates the conditions for mineral precipitation (Burne and Moore, 1987). Therefore these organisms do not have the capacity to create a shell or a hard structure that could be left in the fossil record, not always recognizable and often confused with other types of organic processes (Brasier et al., 2002).

Stromatolitic records suggest that life began in the Earth about 4,000 millions years (My) ago, according to the stromatolites found in sedimentary rock sequences in Greenland dated 3,700 My (Nutman et al., 2016), surpassing the stromatolites found in rocks of the Warrawoona Formation in western Australia, dated 3,450 My (Hofmann et al., 1999). Since then to the present, the stromatolites are still forming in shallow water environment in different places around the planet (Hoffman, 1976; Playford and Cockbain, 1976; Walter et al., 1972; Chizuru and Akihiro, 2005; Takashima and Kano, 2008; Jones et al., 2005; Dravis, 1983; Reid et al., 1999; Souza et al., 2006; Souza et al., 2012; Pedley, 2000), even in brackish lakes and salars in both sides of the Andes Mountain Range, where the environmental conditions are sufficient for the development of these organisms. Stromatolites has been reported in the Salar de Llamara (Demergasso et al., 2003; Rasuk et al., 2014), in the lakes Laguna de la Piedra (Stivaletta et al., 2011, Laguna Tebenquiche and Brava (Farías et al., 2014) in Chile, and in the volcanic lake Laguna Socompa in Argentina (Farías et al., 2013).

In general, stromatolites are commonly formed by calcium carbonate as the mineralizing element, in water with relative low salinity conditions, in order for these organisms to develop. Occasionally gypsum, is an active mineral in the formation of these structures, as shown in examples in Australia (Warren, 1982), the border between Ukraine and Poland (Babel et al., 2011), Cyprus and Crete (Allwood et al., 2013) and Chile (Demergasso et al., 2003, Rasuk et al., 2014), mainly because the salinity conditions for gypsum formation are close to the limit of salinity for the survival of these organisms in the environment (de Wit et al., 1988).

The purpose of this paper is to describe the physical process of formation an evolution of these gypsum stromatolites, located in salars at high geographical altitude (over 3,500 $\mathrm{m}$ a.s.1.), from the formation of the microbial mat to the final stage, when erosion occurs and the organic action terminates over time. This information shows a vision that aids in the recognition and understanding of this type of structures in the geological records.

The data presented in this paper were taken in two fieldwork campaigns in the months of April 2013 and April 2014, as part of the study of Troncoso et $a l$. (2013) and it is based in field observations.

\section{Description of the study area}

The study area (Fig. 1) is located in the Andes highlands of the Antofagasta and Atacama regions, in Chile, near the border with Argentina. Regionally, the area is part of a volcanic arc of upper Cenozoic age. This results in a high concentration of volcanic centers (more than 100) that form different endorheic basins where the salars are situated.

Most of the study area is covered by different volcanic rock sequences (Fig. 1) related to the different well preserved emission centers, with varied complexities and extensions. These volcanic rock sequences extend temporally between the Miocene and the Holocene (Naranjo et al., 2013 a, b). Ignimbrite is the most abundant lithology rangin in age from Lower Miocene to Pleistocene, defined by three main units: Ignimbritas Río Frío (Lower Miocene), Ignimbritas Pajonales (Lower to Middle Miocene) and the Ignimbrita de Caletones Cori (Pleistocene). The ignimbrites are partially covered by younger volcanic rocks, (mainly dacitic and andesitic) (Naranjo et al., $2013 \mathrm{a}, \mathrm{b}$ ).

The salars (or salt flat) are found in endorheic basins formed by the volcanic processes since the Miocene (Naranjo et al., 2013 a and b).

The different stromatolite bearing areas are located (Fig. 1) in five salars at the border between the regions of Atacama and Antofagasta, in northern Chile, close to the border with Argentina. They are situated at an altitude higher than 3,000 m a.s.1. in a zone characterized by low temperature (e.g., $2{ }^{\circ} \mathrm{C}$ average annual temperature at 3,500 $\mathrm{m}$ a.s.l.) and high radiation and evaporation rates $(1,000$ $2,500 \mathrm{~mm} /$ year). The water of the lagoons present in the salars display high salinity (e.g., conductivity up to $200,000 \mathrm{mS} / \mathrm{cm}$ and sulfate concentration up to $107,000 \mathrm{mg} / \mathrm{l})$ and variable $\mathrm{pH}(2-8)$. 


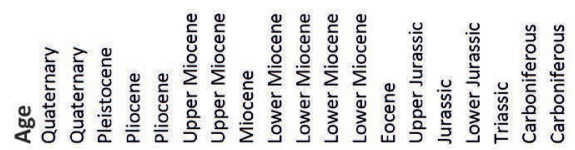
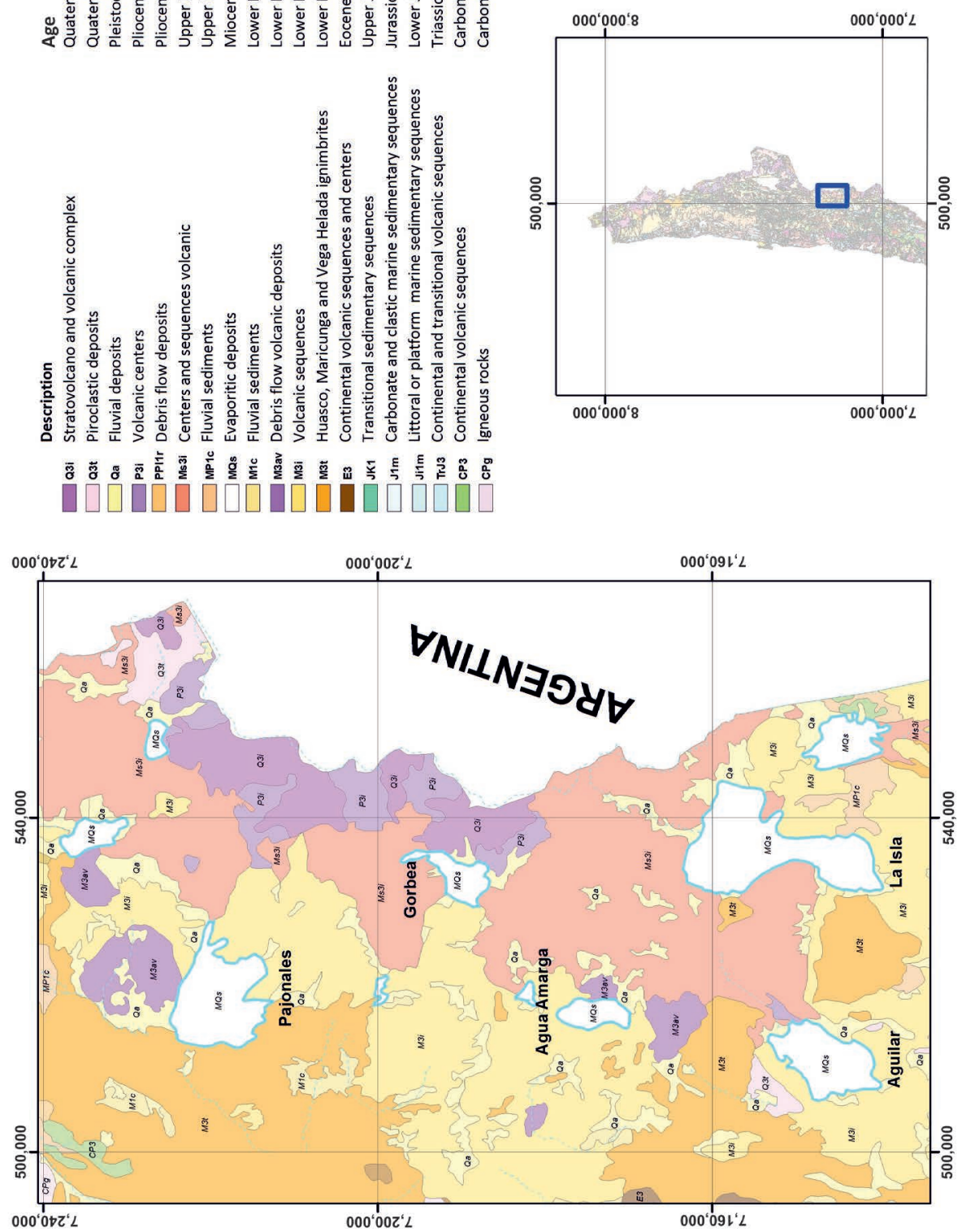

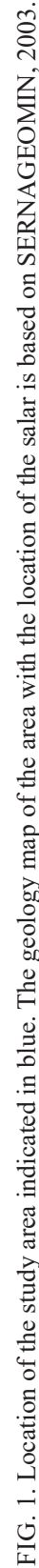


The following is a general description of the salars hosting stromatolites, includes in this study.

The Pajonales Salar (Fig. 1), located in the southeast of the Antofagasta Region, is part of an endorheic basin of $1,984 \mathrm{~km}^{2}$ with a surface of $104 \mathrm{~km}^{2}$, at 3,537 $\mathrm{m}$ a.s.1 and composed of salt crusts.

The salt crust consists of a rough crust, somewhat irregular, with a composition of sulfate and with a minor concentration of borates. The edges of the brackish lagoons, in the northwest part of the salar, have halite chevron type crystal growth.

The Agua Amarga Salar (Fig. 1) is located 34 km to the south of Pajonales Salar at 3,558 m a.s.l, in the Atacama region, and has a surface of $23 \mathrm{~km}^{2}$ of saline crust, in a basin of $863 \mathrm{~km}^{2}$. There are three different types of crusts. The first, located to the west border of the salar, is a rough and extremely irregular crust, with great differences in elevation in a short horizontal distance (up to $50 \mathrm{~cm}$ ), formed by halite and eolic sediments that give the halite a brown color.

The second one is located to the east, in the central part of the salar. It is formed by halite with polygons formation and has several lagoons and small circular lagoons in the northern part, in which it is possible to see gypsum stromatolites covered by halite.

Along the east border, there is a third type of saline crust, which is the most extensive. It is formed mainly by gypsum crystals of several sizes, probably including gypsum from older stromatolites, because the similarities with crystal observed in stromatolites located to the southeast and north of the salar.

The location of the lagoons and the mineral distribution indicates that the basin of the salar has the lowest altitude in the zone with the second type of halite saline crust, which receives groundwater input from the north and west.

The Gorbea Salar (Fig. 1) is located in the Antofagasta region, very close to the border ChileArgentina at 3,950 $\mathrm{m}$ a.s.l. It has a saline crust extension of $27 \mathrm{~km}^{2}$, in a basin with an area of $324 \mathrm{~km}^{2}$.

The main saline crust is formed by a mix of halite and thenardite that is white, dusty and has a thickness of $1 \mathrm{~cm}$ and covers an orange more compact layer with a thickness of $5 \mathrm{~cm}$. On this external layer, it is possible to see cotton ball structures, which normally are made by ulexite or the borate mineral group. In other places, there are green or intense yellow covers, the last one more extensive in the northeast and is formed by native sulfur. The second saline crust is formed by gypsum in mounds up to $2 \mathrm{~m}$ high in the south and $4 \mathrm{~m}$ high in the north, with crystals that can be $20 \mathrm{~cm}$ long, showing structures like fish bone. The gypsum forms a superficial layer next to several lagoons with black waters with sulfur that precipitates under the water. The third saline crust is located to the south, with crystalline thenardite mounds and a thin superficial layer of dust of the same mineral.

The lagoons have a $\mathrm{pH}$ lower than 2 with high concentrations of sulfates $(74,290$ to $107,367 \mathrm{mg} / \mathrm{l})$ (Troncoso et al., 2013).

The La Isla Salar (Fig. 1) is the most extensive, with an area of $152 \mathrm{~km}^{2}$ inside a relatively small basin of $858 \mathrm{~km}^{2}$, located in the northest of the Atacama Region, at 3,950 $\mathrm{m}$ a.s.1.

The salar has two different types of saline crusts in the north and the south, with a progressive transition from one to the other. In the northern zone, the saline crust is mainly composed of sulfates (mainly gypsum), with a slightly irregular surface, that contains small gypsum crystals. This is more closely visible around the called "islands", which are volcanic outcrops surrounded by the saline crust with a $3 \mathrm{~m}$ band where the gypsum crystals of different sizes accumulate at the base.

This sulfate rich crust passes progressively to the south towards a crust formed by a very thin layer of halite (1 to $2 \mathrm{~mm}$ ), which precipitates over a sand-silt layer, about $5 \mathrm{~cm}$ thick, with an important discomposed organic material underneath in it, with colors in black and a characteristic "rotten egg"? strong smell.

It is interpreted that the basin is tilted towards the south, where the halite layers and the terrigenous material are covered by a very thin layer of water. To the north and northeast, there are lagoons composed of saline water saturated in halite, with this mineral deposited on the shores of these lagoons.

The Aguilar Salar (Fig. 1) is located in a basin with an area of $589 \mathrm{~km}^{2}$ and the salar has a surface of $71 \mathrm{~km}^{2}$, in the northeast part of the Atacama region at 3,320 $\mathrm{m}$ a.s.1.

The saline crust can be differentiated into three types. The main crust is located to the west boder of the salar, and it is formed by halite with a surface very irregular and dark brown color produced by eolic deposits.

Towards the east, there is a second saline crust that extends from north to south. The surface is more 
regular and enriched in sulfates (mainly gypsum), with a light brown and relatively hard superficial crust, 3 to $4 \mathrm{~cm}$ in thickness, while underneath there is another layer, $10 \mathrm{~cm}$ in thickness, formed by disaggregated halite crystals, sometimes pale orange in color and white, with some humidity.

The third type of saline crust, whitish to light brown in color is located in the estern and southern zones of the salar. This sulfate rich crust includes gypsum mounds that extend outside the actual limits of the saline crust to the northeast. They are 9 and $12 \mathrm{~m}$ high above the actual level of the salar, and they are interpreted as evidence of paleoshores.

The fact that the development of the salar surface was greater than its current extension is demonstrated by the serial paleolagoons located in the northern margin. These are found 50 to $100 \mathrm{~m}$ from the actual position of the salar and they are covered by a layer of modern sediments transported there.

\section{Gypsum stromatolites evolutionary stages}

With the available information and field observations, it has been possible to stablish a possible evolutionary pattern for the stramatolites structure from its origin until their partial destruction by erosive agents. Initially, the observations were dispersed pieces, where determinated areas in each salar showed only a portion of the sequence that it is described here. The global study of these observations has permitted to define six evolutionary stages, the first three with organic influence and the last three do not, as described below (Fig. 2).

\subsection{Stage 1: Mat growth}

The first stage consists of a microbial mat that grows in shallow saline water. The colonies observed were located in lagoons with different extensions, but with a maximum water depth of $20 \mathrm{~cm}$ approximately and the mats touching the water surface in some cases (Fig. 3A).

These mats show a homogeneous light brown color and when is touching they are gelatinous, similar to sensation of touching an algae. When an attempt was made to take a sample, it was possible to verify than the light brown color is due to loose sediment deposited on their surface that when removed, the mats showed their original white color (Fig. 3B).
These sediments that cover the microbial mat have a double origin. A part is attributed to dust and fine grained sediments transported by the wind from the surrounding zones. The other part, the most important, is made up of crystal formed in the lagoon that precipitate to the bottom of it, possibly formed by gypsum and minor calcite or another type of carbonate. This coincides with Babel (2004) and Thompson and Ferris (1990), indicating that some organisms trap sediments and crystals formed in saline lagoons to create mineral structures.

In regards to the organisms that form the organic mat, Demergasso et al. (2003), AzúaBustos et al. (2012) and, especially, Rasuk et al. (2014), suggest that similar mats are formed by Proteobacteria (Alpha and Gamma), Bacteroidetes and Planctomycetes, with a small contribution of Cyanobacterias. In some zones near these growth places, stromatolites have been formed displaying a clear microlayering (Fig. 3D). Additionally, in an area located to the southeast of Agua Amarga Salar, the organisms formed oncolites, several centimeters in diameter, which display a layering surrounding a nucleus (Fig. 3C).

The organic mats and the initial stromatolitic formations have been observed in lagoons located in the Aguilar (Fig. 2E) Agua Amarga (Fig. 2B) salars.

\subsection{Stage 2: Upholstery of the mat}

In this second stage the mats still have their flat appearance, but start to show bulbing. These have a circular form, with a diameter from a few centimeters to $50 \mathrm{~cm}$ in the largest structures, with about $5 \mathrm{~cm}$ high above the base level. These structures show in their surface the firsts gypsum crystals, with pale brown color (Fig. 4).

These structures are soft and breaking through without difficulty when they are punctured. From this hole, many gas bubbles emanated which could be responsible for the bulbing observed in these structures. The wall of the structure acts like as an impermeable layer, but flexible enough to be deformed and could behave as a balloon, keeping the gas inside. This gas probably is a product of the organic activity. Similar structures have been described in the Laguna Tebenquinche y Brava by Farías et al. (2014), indicating that the structures of this kind were generated by gas accumulation, but without establishing the compounds responsible. 

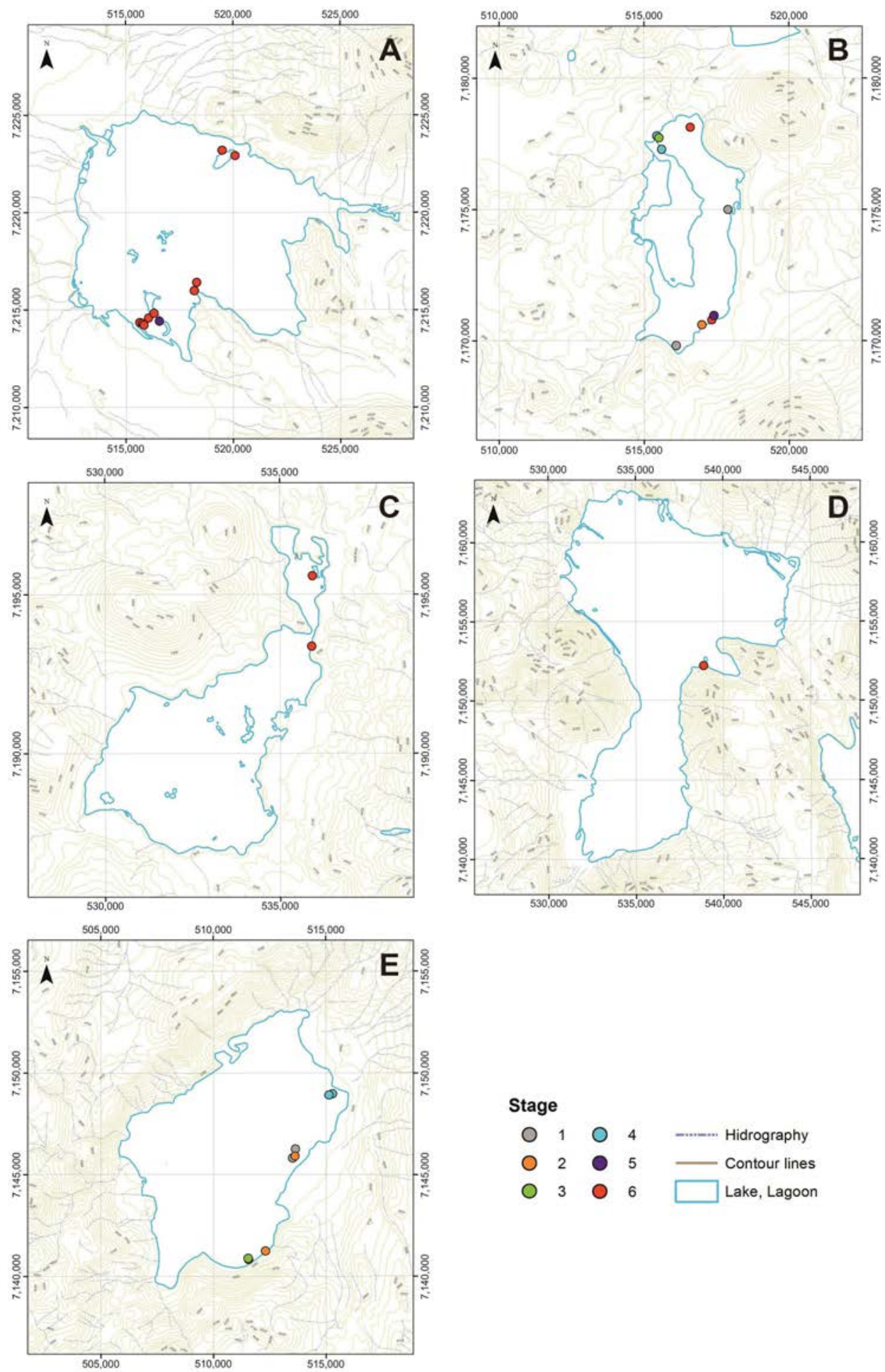

FIG. 2. Topographic maps of salars considered in this study, the color spots indicate the localization of stromatolites and their different evolutionary stages. A. Pajonales Salar; B. Agua Amarga Salar; C. Gorbea Salar; D. La Isla Salar; E. Aguilar Salar. 


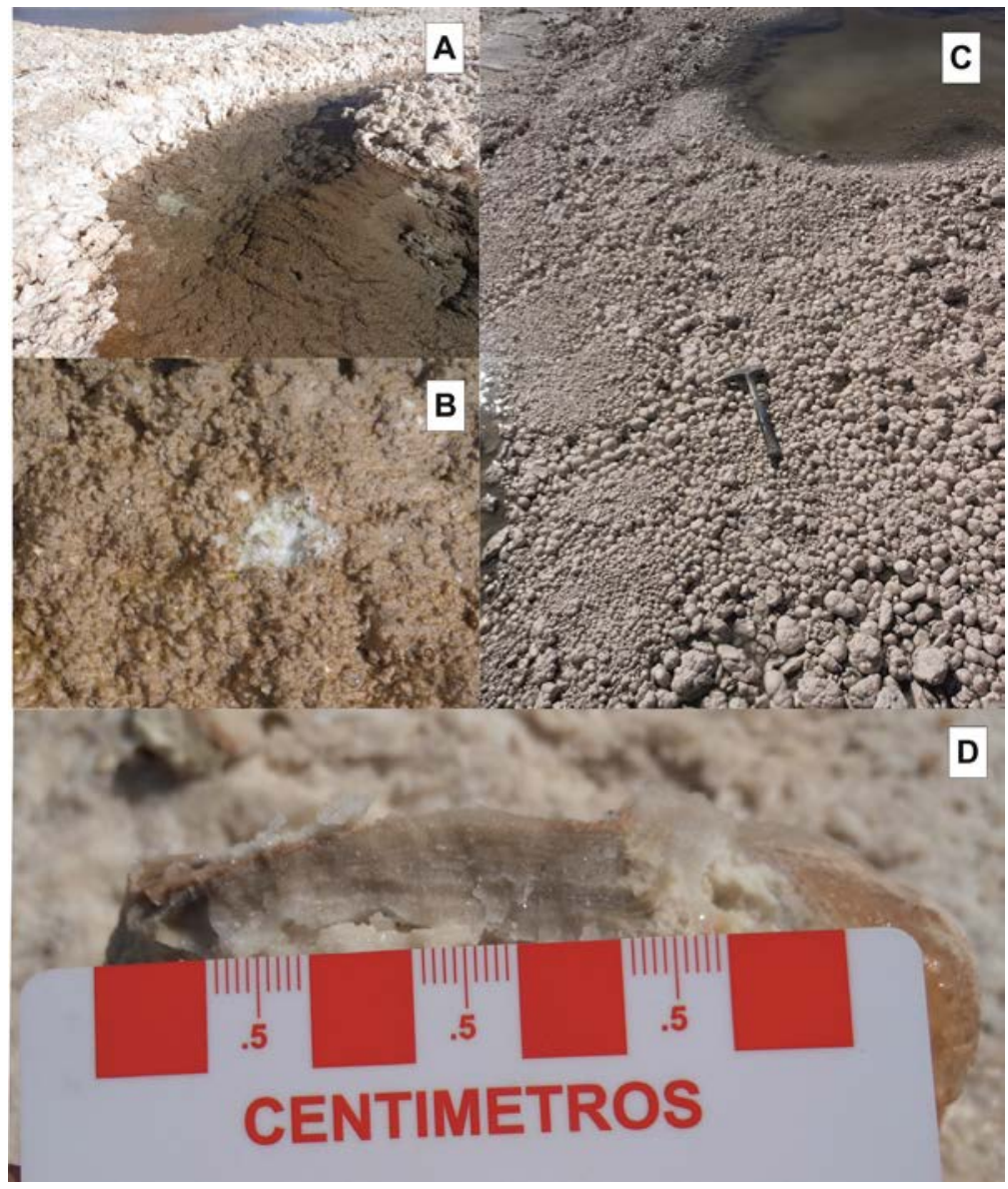

FIG. 3. A. Organic mat on the bottom of a lagoon; B. Detail of the mat and its white color after removing their dust cover; C. Oncolites; D. Detail of lamination in a stromatolite (Agua Amarga Salar).

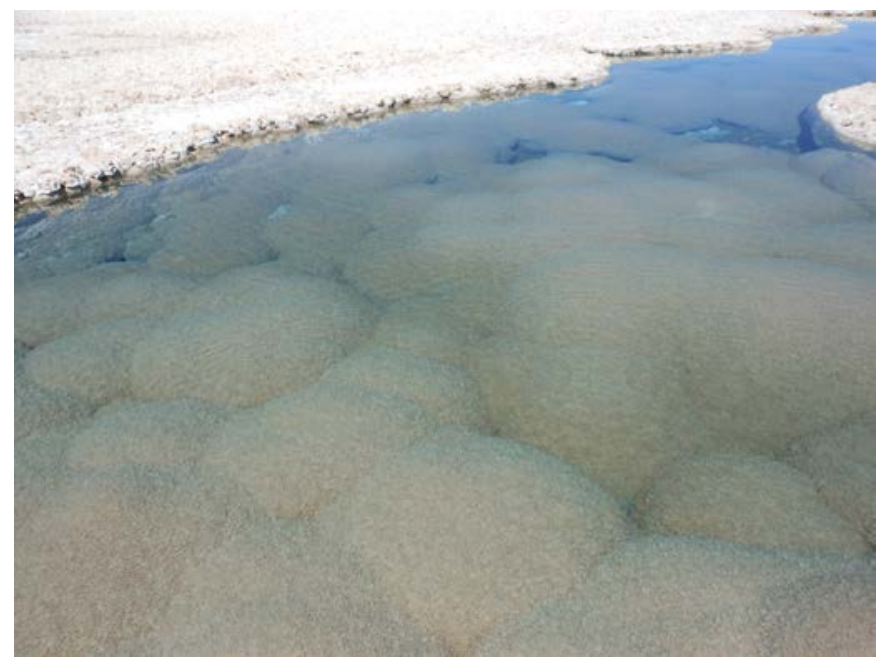

FIG. 4. Stromatolites in a shallow water lagoon in Agua Amarga Salar. The image is $2 \mathrm{~m}$ width. 
The gas was detained under the organic mat, acting like a reservoir and starting to deform as accumulation became more important. The gas content, not analyzed, could be oxygen, carbon dioxide or another type of volatile compound generated during the organic activity or a combination of them inclusively.

Initially, these structures are not stable by themselves, except for their floatability and protection that the water provides, less if the organic mat is thin. Therefore, the precipitation of gypsum, the capture of those crystals by the organisms and/or the growth of these from their organic surface, would grant greater stability to the structure for its preservation.

\subsection{Stage 3: Forming the gypsum cover}

This stage is characterized by the formation of a mineral cover thicker than in the previous mentioned stages. The external mineral cementation is stable and continuous, and clearly maintains the dome-shaped structures of stage 2, forming an irregular layer of gypsum crystals (Fig. 5A).

Farías et al. (2014) suggest that the formation of these structures is due to an increase in the salinity of the medium. This coincides with that observed in the field, where the most of the structures of this kind are found in extremely shallow lagoons, forming platforms at the surface of the water. The water is saturated in $\mathrm{NaCl}$ and halite precipitates on some of these domes (Fig. 5B). In addition, the irregular morphology of the gypsum crystals indicates that they form in stages where the enzymatic processes are still active, meaning that the organisms that conform the mat are alive (Warren, 2006).

Evidences of this stage can be observed in lagoons to the western area of Agua Amarga Salar (Fig. 2B) and in the east zone of Aguilar Salar (Fig. 2E).

\subsection{Stage 4: Crystal growth}

This stage is determined by the death of the organic colony that built the stromatolite. It is separated into two different types.

In the case of the stromatolites formed in shallow water lagoons (e.g., a few $\mathrm{cm}$ ), the water progressively evolves into brines, where halite forms and precipitates over the stromatolitic structures (Fig. 6A). This could be the result of tectonic uplift, which reduces water recharge towards the lagoon with time or an increase of the evaporation ratio, causing a decrease in the water level and an increase in the saline saturation.

For those domes structures developed in lagoons with deeper water (up to several meters), the stromatolite structures are bigger and solitary, meters in diameter (Fig. 6B).

With the death of the organisms and the end of the enzymes generation, that previously modified the gypsum crystalline structure, the new crystals start to grow with regular forms, with fishbone twins towards the surface and to the empty central part of the structure, described in the previous stage.

When the domes are exposed above the water surface, they start its breakdown and someone of its parts collapse. This was observed in that cases where

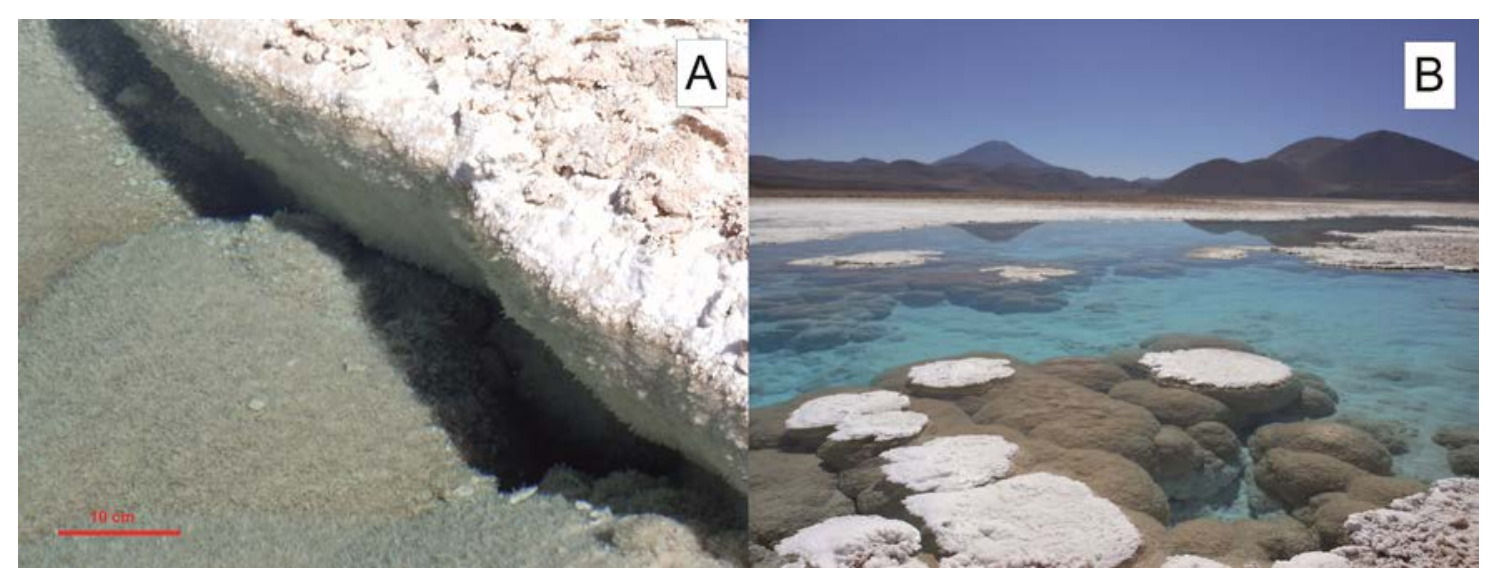

FIG. 5. A. Detail of stromatolites covered by water with gypsum crystals on their surface; B. Stromatolites with halite deposits on the surface exposed above the water level (Agua Amarga Salar). 


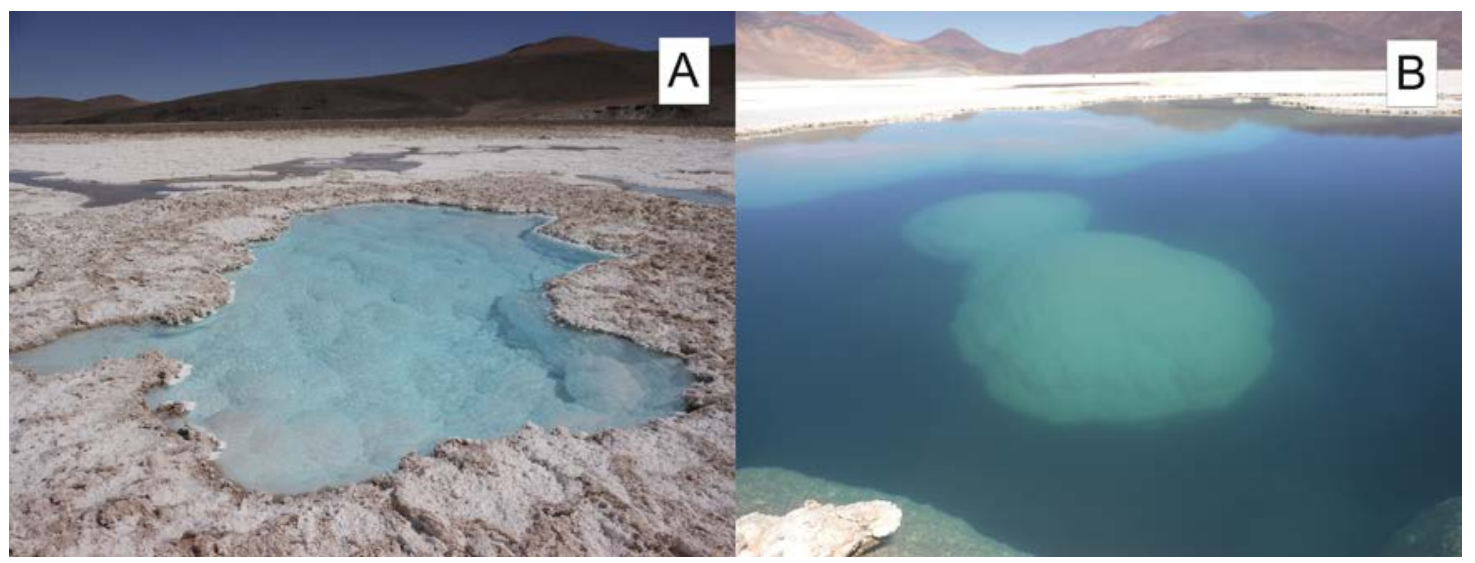

FIG. 6. A. Stromatolites covered with halite in a shallow water lagoon (10 to $15 \mathrm{~cm}$ ) (Agua Amarga Salar); B. Large stromatolite (2 to $2.5 \mathrm{~m}$ in diameter) in a lagoon, in a deep of less of $1 \mathrm{~m}$ in the salar de Aguilar.

the interior of the domes were completely empty and the domes are composed of long gypsum crystals, saber type, up to $20 \mathrm{~cm}$ in length (Fig. 7C). Those crystals were orientated with the largest axes towards the center of the dome, with a light brown color in the external side and white in the internal. The crystals have a fishbone twin, marking different growth phases. The presences of these stromatolites are an important indicator to recognize paleobathymetries, since it has been observed that they grow in lagoons of certain depths

This stage has been observed in Agua Amarga Salar (Fig. 2B) and Aguilar Salar (Fig. 2E), through the domes still submerged in the lagoons, and in Agua Amarga Salar (Fig. 2B) and Pajonales Salar, by the structures emerged on the surface and surrounded by the saline crust.

\subsection{Stage 5: Start of the erosion}

This stage has only been described in the larger domes described previously (Fig. 7A). The structure collapse at some point when it gets out of the water, which has been protecting it. When it is opened through a fracture (Fig. 7B), the empty space inside begins to fill with material transported by the wind, mainly salt and parts of the crystalline material of the same dome (Fig. 7D).

This type of structures with similar gypsum crystals has been described by Peryt (2013) and Babel et al . (2011) in Miocene deposits in Poland and Ukraine, but these authors do not interpret if these structures are associated with microbialites or stromatolites. However the stratigraphic columns included in the papers, show the layers with gypsum crystals deposited over layers described as stromatolitic deposits.

This stage can be observed in Pajonales Salar (Fig. 2A) and Agua Amarga Salar (Fig. 2B).

\subsection{Stage 6: The final traces}

In this point of the process, the final degradation of the structure occurs.

Once the fill of the dome is complete, the structures that remain have an inferior part formed by fine grained sediment in which gypsum crystals with various sizes, some of them amalgamated, conserving the original structure of the crystals, but not its original position, are observed (Fig. 8A). In the superior portion of the mounds, the original part of the domes is observed and the gypsum crystals tend to conserve their original position in most of the cases (Fig. 8B).

Surrounding these mounds, different gypsum crystals, dispersed during the previous stages are observed. These crystals could serve as an index to know the original location of these mounds because they are an exogenous element in saline crusts occuring as breadcrumbs that grow larger towards the mounds.

In some areas, such as the northeast part of $\mathrm{La}$ Isla Salar, the presence of these crystals do not correspond with the actual mounds in the zone, with the closely related mounds located almost six kilometers in distance. 


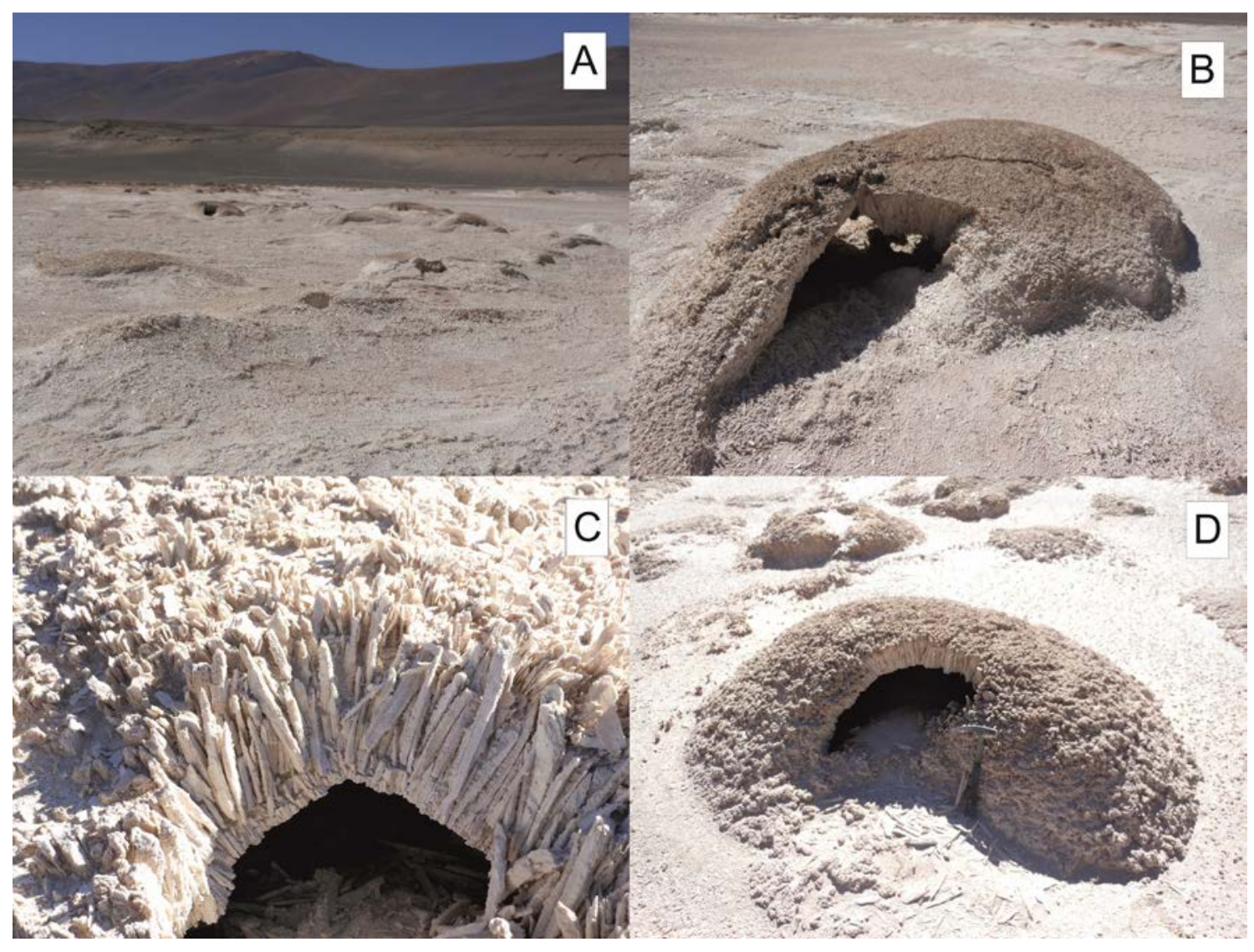

FIG. 7. A. Surface with partially eroded gypsum stromatolite (Agua Amarga Salar); B. Dome shaped stromatolite with collapsed margen (Agua Amarga Salar); C. Detail of the arrangement of the gypsum crystals in the stromatolite wall. The crystals are $15 \mathrm{~cm}$ length (salar de Pajonales); D. Dome shaped gypsum stromatolite with part of its interior filled with fine grained sediment (Pajonales Salar).

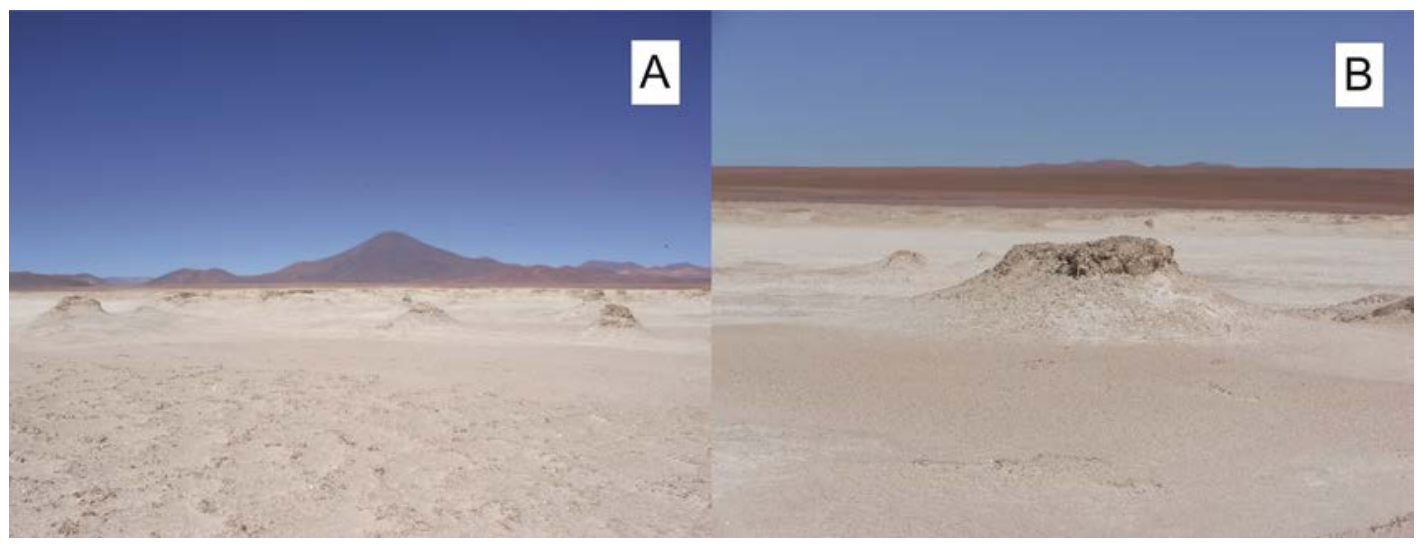

FIG. 8. A. Relicts of stromatolites distributed as scattered mounds (salar de Pajonales); B. Detail of one of these mounds, with the upper part formed by gypsum crystals and accumulation of small gypsum fragments, salts and fine-grained sediments at the base (Pajonales Salar). 
Evidences of this stage are found to the north of Agua Amarga Salar (Fig. 2B), south of Pajonales Salar (Fig. 2A), east of La Isla Salar (Fig. 2D) and to the north of Gorbea Salar (Fig. 2C).

\section{Conclusions}

In several salars of the Andes highlands of Chile, there are lagoons in which microbial mats with capacity to create stromatolites are present. Normally these stromatolites are composed by calcite, but in the study areas they are formed by gypsum.

The studied salars are located in the Andes of northern Chile, above 3,000 $\mathrm{m}$ a.s.1. and the lagoons located in these salars are characterized by high salinity water (conductivity up to $207,000 \mathrm{mS} / \mathrm{cm}$ ) and variable $\mathrm{pH}(2-8)$, with very low temperature during the winter (annual average temperature $2{ }^{\circ} \mathrm{C}$ ).

Based on field observation six evolutionary stages have been recognized for the gypsum stromatolites formed in the salar lagoons. These are:

- Growth of the microbial mat and initial deposition of fine grained sediment and gypsum crystals.

- Doming of the microbial mat, produced by trapping of gases inside.

- Thickening of the crystal gypsum wall.

- Death of the microbial colony and exposition of the stromatolitic structure to the subaerial environment.

- Initial breakdown of the structure by erosive agents and start of the central cavity filling.

- Final degradation of the structures and formation of mounds with gypsum crystal at the top.

\section{Acknowledgements}

The author wants to thank Mr. R. Moscoso and the anonymous reviewer, for the revision and contributions to the text and Miss. N. Muñoz, for the help in the translation.

\section{References}

Allwood, A.C.; Burch, I.W.; Rouchy, J.M.; Coleman, M. 2013. Morphological biosignatures in gypsum: diverse formation processes of Messian (6.0 Ma) gypsum stromatolites. Astrobiology 13: 870-886.

Azúa-Bustos, A.; Urrejola, C.; Vicuña, R. 2012. Life at the dry edge: Microorganisms of the Atacama Desert FEBS Letters 586: 2535-2545.

Bąbel, M. 2004. Models for evaporate, selenite and gypsum microbialite deposition in ancient saline basins. Acta Geologica Polonica 54 (2): 215-245.
Bąbel, M.; Olszewska-Nejbert, D.; Bogucki, A. 2011. Gypsum microbialite shaped by brine currents from the Badenian evaporates of western Ukraine. Advances in stromatolite geobiology. Springer: 257-320.

Brasier, M.D.; Green, O.R.; Jephcoat, A.P.; Kleppe, A.K.; Van Kranendonk, M.J.; Lindsay, J.F.; Steele, A.; Grassineau, N.V. 2002. Questioning the evidence for Earth's oldest fossils. Nature 416: 76-81.

Burne, R.V.; Moore, L.S. 1987. Microbialites: organosedimentary deposits of benthic microbial communities. Palaios 2: 241-254.

Chizuru, T.; Akihiro, K. 2005. Depositional processes of travertine developed at Shionoha hot spring, Nara Prefecture, Japan. Journal of the Geological Society of Japan 111: 751-764.

De Wit, R.; van Boekel, H.M.; van Gemerden, H. 1988. Growth of the cyanobacterium Microcoleus chtonoplastes on sulfide. FEMS Microbiology Ecology 53. Elsevier: 203-209.

Demergasso, C.; Chong, G.; Galleguillos, P.; Escudero, L.; Martínez-Alonso, M.; Esteve, I. 2003. Tapetes microbianos del Salar de Llamará, norte de Chile. Revista Chilena de Historia Natural 76: 485-455.

Dravis, J.J. 1983. Hardened subtidal stromatolites. Science 215: 385-386.

Farías, M.E.; Rascovan, N.; Toneatti, D.M.; Albarracín, V.H.; Flores, M.R.; Poiré, D.G.; Collavino. M.M.; Aguilar, M.; Vázquez, M.P.; Polerecky, L. 2013. The discovery of stromatolites developing at $3570 \mathrm{~m}$ above sea level in a high-altitude volcanic lake Socompa, Argentinean Andes. PLoS ONE 8 (1): e53457. doi:10.1371/journal. pone.0053457.

Farías, M.E.; Contreras, M.; Rasuk, M.C.; Kurth, D.; Flores, M.R.; Poiré, D.G.; Novoa, F.; Visscher, P.T. 2014. Characterization of bacterial diversity associated with microbial mats, gypsum and carbonate microbialites in thalassic wetlands: Tebenquiche and La Brava, Salar de Atacama, Chile. Springer Japan. Extremophiles, Microbial life under extreme conditions 18 (2): 311-325.

Hoffman, P. 1976. Stromatolite morphogenesis in Shark Bay, Western Australia. In Stromatolites (Walter, M.R.; editor). Elsevier Scientific Publishing Company: 261272. Amsterdam.

Hofmann, H.J.; Grey, K.; Hickman, A.H.; Thorpe, R.I. 1999. Origin of $3.45 \mathrm{Ga}$ coniform stromatolites in Warrawoona Group, Western Australia. GSA Bulletin 111 (8): 1256-1262.

Jones, B.; Renaut, R.W.; Konhauser, K.O. 2005. Genesis of large siliceous stromatolites at Frying Pan Lake, 
Waimangu geothermal field, North Island, New Zealand. Sedimentology 52: 1225-1252.

Naranjo, J.A.; Villa, V.; Venegas, C. 2013a. Geología de las áreas Salar de Pajonales y Cerro Moño, regiones de Antofagasta y Atacama. Servicio Nacional de Geología y Minería, Carta Geológica de Chile, Serie Geología Básica 153-154, 1 mapa escala 1:100.000. Santiago.

Naranjo, J.A.; Villa, V.; Venegas, C. 2013b. Geología de las áreas Salar de Aguilar y Portezuelo del León Muerto, Región de Atacama. Servicio Nacional de Geología y Minería, Carta Geológica de Chile, Serie Geología Básica 151-152, 1 mapa escala 1:100.000. Santiago. Nutman, A.P.; Bennett, V.C.; Friend, C.R.L.; van Kranendonk, M.J.; Chivas, A.R. 2016. Rapid emergence of life shown by discovery of 3,700-million-year-old microbial structures. Nature 537: 535-538.

Pedley, M. 2000. Ambient temperature freshwater microbial tufas. In Microbial Sediments (Riding, R.; Awramik, S.M.; editors). Heidelberg, Springer: 175-186.

Peryt, T.M. 2013. Palaegeographical zonation of gypsum facies: Middle Miocene Badenian of Central Paratethys (Carpathian Foredeep in Europe). Journal of Palaeogeography 2: 225-237.

Playford, P.E.; Cockbain, A.E. 1976. Modern algal stromatolites at Hamelin Pool, a hypersaline barred basin in Shark Bay, Western Australia. In Stromatolites (Walter, M.R.; editor). Elsevier Scientific Publishing Company: 101 p. Amsterdam.

Rasuk, M.C.; Kurth, D.; Flores, M.R.; Contreras, M.; Novoa, F.; Poire, D.; Farías. M.E. 2014. Microbial Characterization of microbial ecosystems associated to evaporates domes of gypsum in Salar de Llamará in Atacama desert. Microbiology Ecology 68: 483-454.

Reid, R.P.; Macintyre; I.G.; Brown, K.M.; Steneck, R.S.; Miller, T. 1999. Modern marine stromatolites in the Exuma Cays, Bahamas-uncommonly common. Facies 33: $1-17$
SERNAGEOMIN, 2003. Mapa Geológico de Chile. Servicio Nacional de Geología y Minería, Publicación Geológica Digital 4 (CD-ROM). Santiago.

Souza, V.; Espinosa-Asuar, L.; Escalante, A.E.; Eguiarte, L.E.; Farmer, J. 2006. An endangered oasis of aquatic microbial biodiversity in the Chihuahuan desert. Proceedings of the National Academy of Sciences of the United States of America 103: 6565-6570.

Souza, V.; Siefert, J.L.; Escalante, A.E.; Elser, J.J.; Eguiarte, L.E. 2012. The Cuatro Ciénegas Basin in Coahuila, Mexico: an astrobiological precambrian park. Astrobiology 12: 641-647.

Stivaletta, N.; Barbieri, R.; Cevenini, F.; López-García, P. 2011. Physicochemical Conditions and Microbial Diversity Associated with the Evaporite Deposits in the Laguna de la Piedra (Salar de Atacama, Chile). Geomicrobiology Journal 28 (1): 83-55

Takashima, C.; Kano, A. 2008. Microbial processes forming daily lamination in a stromatolitic travertine. Sedimentary Geology 208: 114-115.

Thompson, J.B.; Ferris, F.G. 1990 Cyanobacterial precipitation of gypsum, calcite, and magnesite from natural alkaline lake water. Geology 18: 555-558.

Troncoso, R.; Ercilla, O.; Carrasco, R.; Vivallo, W. 2013. Estudio del potencial de litio en salares del norte de Chile, Servicio Nacional de Geología y Minería: 246 p. Santiago.

Walter, M.R.; Bauld, J.; Brock, T.D. 1972. Siliceous algal and bacterial stromatolites in hot spring and geyser effluents of yellowstone national park. Science 178: 402-405.

Warren, J.K. 1982. The hydrological setting, ocurrence and significance of gypsum in late Quaternary salt lakes in south Australia. International Association of Sedimentologists: 605-637.

Warren, J.K. 2006. Evaporites: Sediment, resources and hydrocarbons. Springer: 1035 p. Germany.

Manuscript received: January 01, 2017; revised/accepted: August 07, 2018; available online: September 28, 2018. 